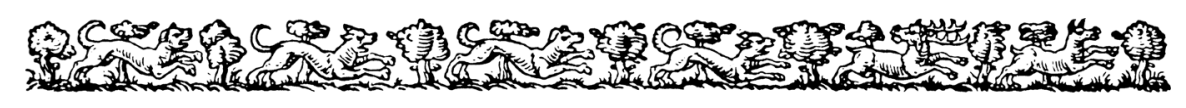

ANTHONY OSSA-RICHARDSON

\title{
Known Unknowns: Sir John Davies' Nosce Teipsum in Conversation
}

Poetry can be criticized only through poetry. A judgement on a work of art, if it is not itself a work of art . . has no civil rights in the realm of art.

— Friedrich Schlegel, Critical Fragment I I 7

$\rrbracket$ he central current of Western verbal aesthetics has always valued elsuasively, and often ornately. In the classical picture, eloquence is a necessary companion of knowledge, especially self-knowledge, if the latter is not to be privately husbanded but put to public political and forensic ends. But a recurrent alternative, one with a frequent emphasis on private over public experience, has found aesthetic value in qualities apparently antithetical to eloquence: silence, bareness, inarticulacy, obscurity, incoherence, nonsense. This strain came to the fore in modernist literature-Prufrock's inability to express himself, say, or the formidable night thoughts of Finnegans Wake-heralded by Hugo von Hofmannsthal's "Lord Chandos Letter" of I902, and given philosophical respectability by the final sentence of Wittgenstein's Tractatus. But that value is heard already in the fragmentation and obscurancy of German romantic criticism, in the intense diffidence of apophatic theology, and in the many vital traditions of nonsense verse from late medieval Europe. Scholars of early modern literature will have no trouble thinking of parallels. Carla Mazzio, for one, has recently made a strong case for the aesthetics of inarticulate utterance on the Renaissance stage, as mumbling, polyglotism, and other types of ineloquence seemed to offer a means to communicate alternative

For their comments on earlier drafts of this essay, I would like to thank David Colclough and Elizabeth Swann. My thanks also to Dilwyn Knox for advice on Plotinus. 
worldviews. Before her Stanley Fish devoted a monograph to what he called "self-consuming" texts, which, he said, subverted communicative norms so as to put the burden of interpretation, and then of selfinterpretation, on the reader. ${ }^{\mathrm{I}}$ There are even glimmers in classical rhetoric itself: Longinus extols the pregnant silence of Ajax's shade in the Odyssey, and Quintilian mentions the trope of reticentia or aposiopesis, in which an orator breaks off mid-sentence to suggest extreme passion.

What all of these modes and devices present, however, is not actual ineloquence or inarticulacy but a simulacrum. Words do not really fail the orator-his faltering precisely conveys his message. Prufrock may find it impossible to say just what he means, but Eliot says it with consummate artistry. Nonsense turns out to contain hidden sense, or else to express a defiant joy in its very senselessness. ${ }^{2}$ In each instance the spectacle of failure is a success, as with the gracefully executed clumsiness of a clown, or a comic routine by Andy Kaufman. ${ }^{3}$ But we are left with the question of how to distinguish such a counterfeit inarticulacy from the real thing, and of what to do with the latter when we have found it. Might genuine ineloquence, as we have long assumed of its simulacrum, serve an aesthetic purpose?

This essay attempts an answer to that question, using as a case study two early modern English poems about self-knowledge, the second a response to the first. Each runs up against the difficulties inherent in the project of representing the self or soul linguistically, but, although they share many presuppositions, the two achieve their effects in very different ways, and each succeeds where the other fails.

II

Sir John Davies' long didactic poem Nosce Teipsum, largely about the nature and immortality of the soul and its relationship to the body, once had

I. Carla Mazzio, The Inarticulate Renaissance: Language Trouble in an Age of Eloquence (Philadelphia, 2009); Stanley Fish, Self-Consuming Artifacts: The Experience of Seventeenth-Century Literature (Berkeley, I972).

2. For another use of nonsense in the seventeenth century, see Rebecca L. Fall, "Popular Nonsense According to John Taylor and Ben Jonson," Studies in English Literature 1500-1900 57 (2017), 87-IIO.

3. This is a version of the paradox critiqued by Catherine Bates, "Astrophil and the Manic Wit of the Abject Male," Studies in English Literature 1500-1900 4I (200I), I-24, although the present essay goes in a rather different direction from hers. The paradox could be applied to other arts: in I955 the architectural critic Reyner Banham wrote of the brutalist school at Hunstanton that "much of the impact of the building comes from the ineloquence, but absolute consistency, of such components as the stairs and handrails": "The New Brutalism," in his A Critic Writes: Essays, ed. Mary Banham (Berkeley, I996), 7-I 5 (I I). 
a high reputation among literary scholars, but is rarely read today. It was first published in I 599, with a dedication to Elizabeth, attempting to recover royal favor after Davies, then a young lawyer, had been disbarred from the Middle Temple for cudgeling a rival. But at least part of it had circulated for some time before-possibly as early as I 592, if we can believe a date assigned it in a copy of the late seventeenth century. ${ }^{4}$ The poem enjoyed early success and was reprinted and adapted several times over the next few decades, sometimes under new titles, such as $A$ Work for None but Angels and Men, printed by Thomas Jenner in I653 with a set of nine engraved emblems. Its adaptation five years later by Jenner as a work of prose seems to suggest what early readers valued in it - paraphrasable content, sententiae, rather than any great beauty — and it long remained a useful resource for illustrating theology in popular discourse, as when John Wesley borrowed a quatrain on prelapsarian reason for a sermon in I77I. ${ }^{5}$

Modern critics have admired Nosce Teipsum without being quite sure what to do with it. In I876 the prolific but slapdash editor Alexander Grosart deemed it intellectually original, ${ }^{6}$ but much scholarship since then has been devoted to reducing it to its sources, from the implausible suggestion of the ancient Neoplatonist Nemesius to two much more likely candidates, the sixteenth-century Huguenot moralists Philippe de Mornay and Pierre de la Primaudaye. ${ }^{7}$ The subsequent consensus has been that Davies had nothing new to say, but said it well. T.S. Eliot wrote of the poem's "remarkable clarity and austerity," and its "great felicity of phrase." G.A. Wilkes, best known as a pioneer in the study of Australian literature, asserted of Davies: "His thinking is not adventurous, and rarely agitated, but the ideas are always brought to finality of utterance." The poet's merit lay in the "smoothness and flexibility of his style." In his critical edition of

4. On the dating, see James Sanderson, Sir John Davies (Boston, I975), I I2-35.

5. John Wesley, "The Law Established through Faith: Discourse II," in his Sermons on Several Occasions, 3 vols. (New York, I 83I), I.387.

6. My own copy of his edition contains amusing manuscript annotations-possibly by the author Charles Lee, to whom it was given in I909 by H. Rivers-Willson-reproving Grosart for "foolish" editorial decisions, such as his note on "abridgement" (I.60), and his suggested emendation of "light" to "hight" (I.76-77).

7. The standard works are now rather antique: E. Hershey Sneath, Philosophy in Poetry: A Study of Sir John Davies's Poem "Nosce Teipsum" (New York, I903); Louis Ignatius Bredvold, "The Sources used by Davies in Nosce Teipsum," PMLA 38 (I923), 745-69; George T. Buckley, "The Indebtedness of Sir John Davies' Nosce Teipsum to Philip Mornay's Trunesse of the Christian Religion," Modern Philology 25 (1927), 67-78.

8. T.S. Eliot, "Sir John Davies" (I926), in On Poetry and Poets (New York, I957), I49-55. 
Davies from 1975, Robert Krueger concurred. ${ }^{9}$ What we seem to have is an efficient machine, or a slick interface for what used to be called the Elizabethan world-picture. ${ }^{\text {Io }}$ Appearances can be deceiving, and few today would assume a theological or philosophical heterogeneity among educated Englishmen of the I 590 s. Nonetheless, the poem's articulacy betrays the soft confidence of authority, of settled questions; it evokes no feeling of discovery or intellectual drama, and Krueger was right, pace J.R. Brink, to say that it lacks the affective charge we now expect from great poetry, including that of Davies' era. ${ }^{\text {II }}$

Moreover, in all the praise for the formal competence of Nosce Teipsum, there is no sense that such a quality is more than incidental to its meaning. A different approach was adumbrated half a century ago by Rosalie Colie, who pointed to Davies' use of paradox - a formal if not necessarily a literary device - to convey the unknowability of the soul. A similar insight has been elaborated in a valuable recent essay by Elizabeth Swann, arguing that "physical metaphors and analogies are instrumental in cultivating a form of knowledge about the soul which is defined, paradoxically, by the limits of such knowledge." ${ }^{2}$ Davies, that is, uses metaphors to estrange the soul from itself, and contradictory metaphors to evoke the essential impossibility of capturing the soul in metaphor. From this perspective, his technique is like those with which we began, communicating, in a sense, by failing to communicate. The virtue of Swann's way is that it reveals the meaning of Nosce Teipsum to be inseparable from its language. But paradox and metaphor are, as she acknowledges, not attributes of poetry alone, and

9. G.A. Wilkes, “The Poetry of Sir John Davies," Huntington Library Quarterly 25 (1962), 28398 (29); Sir John Davies, The Poems, ed. Robert Krueger and Ruby Nemser (Oxford, I975), liv. In the present essay I cite Davies' poem from this edition by line number.

IO. Sanderson, Sir John Davies, I22-23. For a nuanced account of this concept, see David Norbrook, "Rhetoric, Ideology and the Elizabethan World Picture," in Renaissance Rhetoric, ed. Peter Mack (Basingstoke, I994), I40-64. Bernard N. Wills, "Essence and Operation: Sir John Davies on the Nature of the Soul," Heythrop Journal 57 (20I6), 742-52, mounts a defense of the poem's philosophical coherence, albeit not its novelty, and ignores its poetic qualities altogether.

I I. J.R. Brink, review of The Poems of Sir John Davies, in The Review of English Studies 28 (I977), 337-40.

I2. Rosalie Colie, Paradoxia Epidemica: The Renaissance Tradition of Paradox (Princeton, I966), 409; Elizabeth L. Swann, "Nosce Teipsum: The Senses of Self-Knowledge in Early Modern England," in Literature, Belief and Knowledge in Early Modern England: Knowing Faith, ed. Subha Mukherji and Tim Stuart-Buttle (London, 20I8), I95-2I4 (205). Cf. Kevin Killeen's argument in "Poetry and Natural Philosophy: The Errant Soul in John Davies, John Donne and Phineas Fletcher," in The Oxford Handbook of Early Modern Poetry, ed. Andrew Zurcher and Jason ScottWarren (forthcoming). 
the same problem had been faced by all writers on metaphysics from antiquity onwards. What we still lack is an insight into the implications of Davies' specific literary profile- his vaunted "smoothness."

To assess these implications, we need to understand exactly what Nosce Teipsum was trying to do. Its title represented the standard Latin translation of the Greek imperative Gnöthi seauton, "Know thyself," supposedly inscribed above the entrance to Apollo's temple at Delphi. But what exactly was self-knowledge? ${ }^{\text {I3 }}$ According to the Catholic priest Thomas Wright, it "principally consisteth of a perfit experience every man hath of himselfe in particular, and an universall knowledge of mens inclinations in common." ${ }^{14}$ However, if a person wanted "experience" of herself in particular - that is, to acquire what we might today call "self-awareness"it was no use reading a book: the didactic literature had no option but to focus on "universal knowledge," on human nature. The Somerset minister William Chub thus compared the Delphic maxim to the first line of Psalm 8, "What is man, say I, that thou art mindful of him?" " Deborah Harkness has suggested that self-knowledge was the guiding rationale for medicine in this period, and there is evidence that anatomists such as Helkiah Crooke defended their science under this rubric; but it was far more common to think of it, as Cicero had done, as a knowledge specifically of the soul. ${ }^{16}$ For many Protestants, as also for Erasmus, the enterprise was ethical as well as epistemic: self-knowledge was not a disinterested search for truth but an attempt to reform the soul by way of acknowledging one's own weakness and ignorance. In Thomas Jenner's I 626 book of emblems, The Soules Solace, a false, proud sort of self-knowledge that considers the self alone, or by comparison to the weak, is compared to the pleasure taken in pretty flowers, whereas true self-knowledge is the humility called forth by contemplating the self in relation to God, like an eye dazzled, chastened, by the sun. ${ }^{17} \mathrm{~A}$ variation on the theme emphasized human mortality. For instance, in Leonard Wright's I 59I fardel of pieties,

I3. See Rolf Soellner, Shakespeare's Patterns of Self-Knowledge (Columbus, I972), 3-25 on the main classical and early modern tradition.

I4. Thomas Wright, The Passions of the Minde in Generall (I604), 7.

I 5. William Chub, The True Travaile of All Faithfull Christians (I585), 7.

I6. Deborah Harkness, "Nosce teipsum: Curiosity, the Humoural Body, and the Culture of Therapeutics in Late $\mathrm{I} 6^{\text {th }}$ - and Early $\mathrm{I} 7^{\text {th }}$-Century England," in Curiosity and Wonder from the Renaissance to the Enlightenment, ed. R.J.W. Evans and Alexander Marr (London, 2017), I87-208; Swann, "Nosce Teipsum," 202. On the Ciceronian tradition of self-knowledge in Renaissance humanism, see now Rhodri Lewis, Hamlet and the Kingdom of Darkness (Princeton, 2017), 20-26.

I7. Thomas Jenner, The Soules Solace; or Thirtie and One Spirituall Emblems (I626), no. I2. 
Pilgrimage to Paradise, the legend NOSCE TEIPSUM appears over a crude woodcut copy of a skeleton from Vesalius, evidently meant as a memento mori. ${ }^{18}$ Such refigurings are perhaps only another way of asserting that selfknowledge, as it had been understood in the classical tradition, was in fact impossible, given the limitations of human capacities. There was precedent for this, too, in antiquity: the poet Ion of Chios said in the fifth century BCE that, for all the brevity of the Delphic maxim, self-knowledge could be attained by Zeus alone. ${ }^{19}$ As we shall see, such a view would abound in the Protestant thought of early modern England, as elsewhere. But we must take care not to over-generalize, for the same idea could be turned on its head. In I60 I the essayist William Cornwallis claimed not only that self-knowledge was desirable and possible through careful study, but also — and here he quoted Ion's verse - that its acquisition made a person "like unto God." 20

What Davies inherited, then, was not so much a single discourse on self-knowledge as an array of ideas both optimistic and pessimistic. Both voices, in fact, are manifest in Nosce Teipsum, and the tension between them remains unresolved. The poem is divided into a short section entitled "Of humane knowledge," and a much longer one "Of the soule of man, and the immortalitie thereof." The first laments our inability to know ourselves, given the near-extinction of the light of reason:

When Reasons lampe which like the Sunne in skie, Throughout Mans litle world her beams did spread, Is now become a Sparkle, which doth lie

Under the Ashes, halfe extinct and dead:

How can we hope, that through the Eye and Eare, This dying Sparkle, in this cloudie place, Can recollect those beames of knowledge cleare, Which were enfus'd, in the first minds by grace? (6I-68)

I 8. Leonard Wright, Pilgrimage to Paradise (I591), I3.

I9. Ion of Chios, Apospasmata, in his Testimonia et fragmenta, ed. Luigi Leurini (Amsterdam,

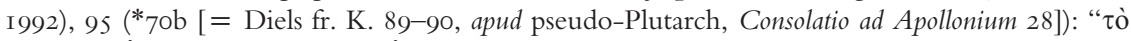

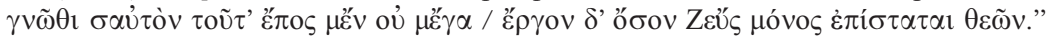

20. William Cornwallis, "Of Sorrow," in Essayes by Sir William Cornwallis the Younger, ed. Don Cameron Allen (Baltimore, I946), I65-66. The verse is quoted from the Latin translation in Plutarch, Opera, quae extant, omnia, tr. Hermannus Cruserius (Frankfurt am Main, I 580), I 59. 
This much was Calvinist cliché. The spark was a conventional symbol for what had been known since Jerome as synderesis or conscience, the highest part of the soul that immediately intuited correct moral judgements; Calvin repeatedly insisted, against the older Catholic tradition, that such a spark was too weak in fallen human beings to guide them in the world. ${ }^{21}$ That Davies' question ("How can we hope ... ?") is merely rhetorical is confirmed by his next analogy to a man seeking to recoup his father's loss of a thousand pounds with a job paying a groat a day-a task that would require I64 years. Following the poet's logic at this point, the search for self-knowledge, at least by "reason's lamp," is simply futile. In fact, the very idea of self-knowledge embodied in the Delphic command smacks of pagan arrogance and curiosity - the desire to know what is forbidden to us, or beyond our capabilities - which in turn was the work of Satan and his oracle:

For how may we to other things attaine?

When none of us his owne soule understands?

For which the Divell mockes our curious braine,

When know thy selfe, his oracle commands. (8I-84)

It would seem inevitable that the philosophical enquiry into the nature and seat of the soul is doomed to failure. Davies lists those who place the soul in the heart, those who put it in the liver, and those who say it is "all in all, and all in part" (225-28), as the scholastics did; he concludes that "these great Clerks, their litle wisdome show, / While with their Doctrines they at Hazard play" (229-30). The overbearing message at this stage appears to be that self-knowledge, the knowledge of the human soul, is made impossible by the soul's own dim powers, as evidenced by the speculations of scholastic theologians and especially heathen philosophers.

But in the longer second section Davies rows back on his initial message, a movement that occurs not once but multiple times. ${ }^{22}$ Deep into the poem, for example, he explains, following Mornay, that although reason in the embodied soul is a mere dusky spark, it has the capacity to become a blaze if endowed with grace:

2 I. Robert A. Greene, "Synderesis, the Spark of Conscience, in the English Renaissance," Journal of the History of Ideas 52 (I99I), 195-2I9.

22. Nosce Teipsum was not the only philosophical poem of the period to exhibit this ambivalence: see, for instance, Kathryn Murphy, "Fulke Greville's Figures of Repetition," Essays in Criticism 65 (2015), 250-73, on Greville's verse "Treatise of Humane Learning." 
Yet hath the Soule a dowrie naturall,

And sparcks of light some common things to see;

$[\ldots]$

And yet these sparks grow almost infinite,

Making the world, and all therein their food;

As fire so spreads, as no place holdeth it,

Being nourisht still, with new supplies of wood. (I I 85-86, I I93-96)

Between these verses is a description of the conscience as natural laws written in the heart, a metaphor that chimes with the dowry but jars with the sparks - sparks next likened to the jars of oil that Elisha multiplied endlessly to pay off a widow's debts (2 Kings $4: 1-7$ ). That miracle had been a prototype of Christ's at Cana, and for Davies it is Christ himself, "that Just one," who now multiplies the soul's sparks by justification, that is, by the operation of grace. The copia of imagery delights us with its inventive energy, its steady, elegant tone, and its webs of biblical associations, but it also serves to obscure Davies' sleight-of-hand as he shifts from insufficiency to sufficiency, from the Calvinist impossibility of selfknowledge to a new optimism founded on Aristotelian reasoning and guaranteed by the magical wand of divine grace. It is the same grace that makes possible the poet's own insights:

This Lampe, through all the Regions of my braine,

Where my Soule sits, doth spread such beames of grace,

As now me thinks, I do distinguish plaine,

Each subtill line of her [i.e., the soul's] immortall face. (26I-64)

Indeed, the poem's didactic content-the nature of the soul, its immortality, its union with the body - would be unknowable, and therefore incommunicable, without the optimism legitimated by his faith in God's action upon his soul. Supposedly endowed with grace, Davies now joins company with those metaphysicians, those "great clerks," at whom he had previously sneered, and in doing so, he seems to renounce his scorn entirely; as Antonio would say of Gonzalo a decade or so later, his end forgets his beginning. Some of those clerks, we recall, proclaimed that the soul existed "all in all, and all in part," and now Davies brazenly goes along with them:

But as the faire, and cheerefull morning light,

Doth here, and there, her silver beames impart, 
And in an instant doth her selfe unite

To the transparent Aire, in all and part:

[...]

So doth the piercing Soule the bodie fill;

Being all in all, and all in part diffus'd,

Indivisible, incorruptible still,

Not forc't, encountred, troubled or confus'd. (909-I2, 9I7-20)

The comparison of the soul and body to the diffusion of sunlight in the air, which Krueger traces to Nemesius, is found already in Plotinus a century earlier; the formula "all in all and all in part" is ultimately from Aristotle and recurs in both Augustine and Thomas Aquinas. ${ }^{23}$ The latter is a paradox typical of attempts to represent the soul, in that it uses the language of spatial location to undermine the idea that the soul has location: to say that all of one thing exists in all of another is to deny that either exists in the other, and specifically in this case to deny that one part of the body contains the soul. Such images, when first devised, and first revived, would no doubt have had precisely the defamiliarizing effect we have seen attributed to the images of Davies' poem. But to an educated reader of Nosce Teipsum, seeking little more than to have his own beliefs elegantly reiterated, they would have been familiar. Plotinus had put the sunlight analogy forward with some tentativeness - suggested it, with a query, as a novel and better solution to the soul-body problem. For Davies, by contrast, that argument is a done deal, and the reader can hear it in his trim iambic patter, "all in all, and all in part diffus'd." Such a prosodic confidence, lulling the reader, counteracts any disorientation provoked by the poem's rapid imagery, and papers over the contradictions in its argument, such as whether the soul is or is not "all in all" the body, or, more centrally, whether the soul can be known by human reason at all.

The early critics were, I think, correct in their judgement of Nosce Teipsum as stock theology, or even bad theology, beautifully put. But

23. Plotinus, Ennead, ed. and tr. A.H. Armstrong (Cambridge, Mass., I966), 4.3.22: “Ã $\rho$ ' oũv

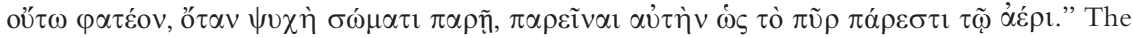
word "pur" here refers not to earthly fire but to sunlight, following Plotinus' commentary on Timaeus $39 \mathrm{~b}_{4}-5$ at Enneads 2.I.I9-24, on which see the notes at James Wilberding, Plotinus' Cosmology: A Study of Ennead II.1 (40): Text, Translation, and Commentary (Oxford, 2006), 2I4-I7. For "all in all," see Aristotle, De anima, 4I rb24, Augustine, De Trinitate, 6.6, and Thomas Aquinas, Summa contra gentiles, 2.72; for a helpful summary of the history see Raymond Waddington, “'All in All': Shakespeare, Milton, Donne and the Soul-in-Body Topos," ELR 20 (I990), 40-68. 
the two quantities are not independent: the poem's eloquence is precisely what permits the incoherences of the subject to remain unchallenged. Drawing on both Calvinist pessimism about self-knowledge and the ethical enquiry recommended by Erasmus and other humanists, Davies allows both to stand side-by-side, unreconciled; his manner reflects the assured conversation of learned friends, not the heat of philosophical or theological battle. This proved a winning combination, as the work's popularity over the next century fully demonstrated. But it also set the stage for a very different sort of poem, one that sought to undermine the substance of Davies' treatise by theological argument, but instead subverted its premise by sheer ineloquence.

Nosce Teipsum, as well as being reprinted, adapted, illustrated, paraphrased and quoted, occasioned a response. This appeared in a poem extant in a single manuscript of twenty-one folios, British Library, Royal MS I8A LXIX, penned in a neat hand as a presentation copy for James I, probably in the first decade of the new century, since its author claims (fol. 2I) initial patronage by Elizabeth. ${ }^{24}$ It is entitled A Christian Reformation of Nosce Teipsum, by the otherwise unknown and unidentified Robert Chambers, certainly not the contemporary Catholic writer of that name. A representative selection, comprising a I 57 -line section "Of humane knowledge," appears in the Appendix. The poem imitates the verse form of Davies' original, and concludes with a prose statement, in fifteen points, of its theological claims. It is little known, but in 1960 was the subject of an essay in Modern Philology by R.H. Bowers, a scholar of medieval and early modern literature at the University of Florida, who worked from rotographs of the manuscript. ${ }^{25}$ Unfortunately, these images seem to have been of poor quality, since his transcriptions were inaccurate, and led to several misunderstandings, starting with the peculiar decision to label the poem a "continuation" of Nosce Teipsum.

In Bowers' defense, the poem's relation to the original is not straightforward. A manuscript catalogue of I92 I calls it a "criticism" of Davies, a

24. References to the manuscript are given by folio in the main text.

25. R.H. Bowers, “An Elizabethan Manuscript 'Continuation' of Sir John Davies' Nosce Teipsum," Modern Philology 58 (1960), I I-I9. See also Soellner, Shakespeare's Patterns, 27-28, indebted to Bowers. 
judgement borne out by the poem's formal apparatus: it is framed as a point-by-point rebuttal of Nosce Teipsum, and begins with a table of the original with page and line references to his own objections. ${ }^{26}$ Crossreferences to Davies are also noted in the margins of the poem. Moreover, Chambers announces his dissent at the start:

Philosophers, with Rules of Arte, and skill they have sett forth an Orator to tell:

He knowes himself; But they have taught him ill, directe O Lorde, he be reformed well.

Whilst on the Stage arayed wth all the Store that Roome or Athens yeldes for such disputes he of the Soule \& Bodye tells, and more, of Gods Decrees, ould Adam he confutes. (fol. 4v)

This figure is not, as Bowers claims, a "strawman" and an "unidentified orator of antiquity," but Davies himself, who has attempted to give an account of the soul upon a foundation of what Chambers sees as pagan rhetoric and philosophy, and in so doing has contradicted the simple piety of the Bible. This will be the basic and recurrent message of the Reformation. However, to see the poem as a mere criticism of Davies does not tell the whole story, for it shares much with the original, from its metre and stanzaic form to its imagery and even verbatim or near-verbatim stanzas. For instance, in his short peroration Chambers quotes the twelve final lines of Nosce Teipsum, on the impossibility of perfect self-knowledge and the virtue of humility, prefaced by a comment of his own:

An Acclamation there is, which trippes againe, tis generall, and in the Soules freewill:

But to conclude with it, my Soule is faine,

I love the good alone, I shunn the ill. (fol. I7)

After the quotation, Chambers admits that "Much more prayse, worthe, this Posye doth conteyne, / with Similes full well and seemelye sett." From this perspective, the Reformation looks more like a review, sifting wheat from chaff in the original, than a simple critique. But a clue lies

26. George Warner and Julius Gilson, British Museum Department of Manuscripts, Catalogue of Western Manuscripts in the Old Royal and King's Collections, 4 vols. (London, I92I), 2.277. 
in the titular word "reformation," whose ambiguity in this period is convenient, for Chambers' poem is both a reform, that is, an improvement (or indeed an improved replacement), and a re-formation or second version of Davies': it at once undermines and underlines its source. In such a respect it echoes the Protestant Reformation itself, understood as both a corrective substitute and a restitution of Catholicism. ${ }^{27}$ When Chambers implores God that Davies "be reformed well," both senses are in play, and it is precisely his own second attempt at a Nosce Teipsum that he hopes will rectify Davies' errant beliefs. To this end his quotations are sometimes altered to make the point:

Soe shall we see, ere our Lampe be spente, and ere the Sprite be dulld, or bodye wann.

Tourninge one volume only, that we hente [i.e., grasp] more then att fyrst, was in the Power of Man.

And fullye knowe, that through the Eye \& Eare, this dyenge sparkell, in this clowdye place:

Can recollecte more gloryouse knowledge here then was infusde in the first Man, by grace. (fol. 6)

Chambers here refashions Davies' rhetorical negative ("How can we hope, that ... ?") as a positive statement of the power of the "one volume," Scripture. The poem as a whole thus operates in a close dialogue with Nosce Teipsum, reiterating and further emphasizing one of its two core tenets - that human reason is corrupt and so incapable of fully knowing itself - while also refining or directly contradicting many of Davies' more specific claims, a tension we may now consider in more detail.

An obvious first query is Chambers' theological affiliation. Bowers is certain that he was a Puritan, given his insistence on human depravity and the centrality of Scripture. But Puritanism was first and foremost a rejection of episcopacy in the English church-as it is, for instance, in the one primary source Bowers cites, William Bradshaw's English Puritanisme (1605) - and that topic is not addressed in the poem. Even if we mean by the term a rigid Calvinism, Chambers' orthodoxy is hard to gauge. Consider, for instance, the origin of the newborn soul. The

27. This duality is in play, for instance, in Thomas Browne's later claim, Religio Medici, I.3, in his Selected Writings, ed. Geoffrey Keynes (Chicago, I970), 8, that "we [Protestants] have reformed from them [Catholics], not against them." 
Catholic church, Calvin, and the Church of England all taught that each soul is created anew by the direct action of God. However, some Church Fathers such as Tertullian and Gregory of Nyssa, and following them Luther, claimed that a person's soul was naturally generated ex traduce, that is, from the souls of its parents. ${ }^{28}$ This doctrine, known as traducianism, conveniently explained the transmission of original sin, but ran the risk of denying God's agency and so resembling materialism. Davies, following La Primaudaye, devotes almost three hundred lines (NT 62 I-876) to rebutting it, and James I, to whom Chambers dedicated his poem, also explicitly rejected it. ${ }^{29}$ Chambers' own position is not immediately clear. He quotes Davies' statement that God took Christ's body from Mary but created his soul, and comments:

Hence I dispute, our Soule descendeth not, to Mothers wombe, from power of God on hie:

As Jesus did, whome Holy ghost begott, soe are we then Tradusde apparantlye. (fol. I2v)

The placement of the negative makes the statement ambiguous: does Chambers "dispute not" that the soul descends from God, or does he dispute Davies' position and assert instead that the soul "descendeth not" from God? Is it that our soul does not descend in the way that Christ's did, but is instead traduced - or is it that our soul does descend, and is "traduced" from God, just as Christ's soul did and was? Given the nature of the work, the ambiguity is unlikely to be the deliberate, "shuffling" sort that Empson decried in Wordsworth; it is probably just incompetent. ${ }^{30}$ The question may seem to be resolved against traducianism by Chambers' declaration (fol. 7v) that "I knowe my Sprite inspird from God above." But intricacies remain, for Chambers evinces qualms with

28. For a summary, see e.g. G.C. Berkouwer, Man: The Image of God, tr. Dirk Jellema (Grand Rapids, I984), 279-308.

29. James I, Basilikon Doron: Or his Majesties Instructions to his Dearest Sonne, Henrie the Prince (Edinburgh, I603), 63. For a more extensive refutation of traducianism by a contemporary English clergyman, see Simon Harward, A Discourse Concerning the Soule and Spirit of Man (1604), 33-42. Takashi Yoshinaka, "The Politics of Traducianism and Robert Herrick," The Seventeenth Century I9 (2004), I 83-95, associates traducianism with Calvinism due to its utility in explaining the transmission of original sin, but offers no example of a Calvinist traducian. For Milton's stance, see Arthur E. Barker, Milton and the Puritan Dilemma, 1641-1660 (Toronto, 1942), 318.

30. William Empson, Seven Types of Ambiguity, 3rd ed. (London, I949), I 54. 
the traditional view held by Davies. In fact, he is sufficiently anxious about the matter to preface his remarks with a disclaimer:

Marke not my Songe, and swere not that I saye, the Soule from parent is tradusd allone:

But powerfull worde of God, and Man that may, I dare avowe, begett us everye one. (fol. I Iv)

He denies simple traducianism, then, but what does he support instead? Not the position found in Nosce Teipsum, which has its own problems: Davies writes (NT 82I-24) that God deprives a soul of grace when he places it into the body at birth, but Chambers sees this as tantamount to a father putting his beloved daughter to work in a brothel, and makes God the origin of evil. The very question seems founded on false premises: "we saye not Soules gett soules as he pretendes: / But Man getts Man" (fol. I2v). The soul cannot be treated apart from the body; rather, the two must be taken together as a whole, an axiom reiterated elsewhere in the poem and confirmed in the prose (fol. 20). Chambers' phrase suggests a form of traducianism articulated by early medical writers and adopted in the sixteenth century by Philipp Melanchthon, Levinus Lemnius, and others. ${ }^{31}$ He may have had it from the 1576 Treatise on the Immortalitie of the Soule by John Woolton, soon to be the bishop of Exeter. Ramie Targoff has stated that Woolton held a simple traducian view, but the words she quotes from his book are paraphrases and quotations of Gregory of Nyssa, used to illustrate one side of the argument. Woolton's own, somewhat provisional claim is that "whole manne proceedeth and is derived of whole manne." ${ }^{22}$ This formula is plausibly the origin of the line in Chambers' Reformation, but it does not neatly map onto the usual confessional categories. Rather than seeing in the poem a simple witness to Puritan thought, then, we need to evaluate it on its own terms-like any other work.

The broader difference in outlook between Davies and Chambers is best represented by their respective attitudes to nature. Davies, recall,

3I. Robert Burton, The Anatomy of Melancholy, ed. Thomas Faulkner et al., 5 vols. (Oxford, 1989), I. I55 (I.i.2.9), summarized the position as follows: "Hippocrates, Avicenna and many late writers [held] that one man begets another, Body and soule: or as a candle from a candle, to be produced from the seed: otherwise say they, a man begets but halfe a man, and is worse then a beast that begettes both matter and form."

32. Ramie Targoff, John Donne, Body and Soul (Chicago, 2008), 93. John Woolton, A Treatise on the Immortalitie of the Soule (I 576), 27. 
had asserted that the soul possessed a "dowrie naturall," adding that "nature" put her laws in the human heart. It is nature by which our sparks aspire to God ("Dedication," I7-20), by whose light "everie senseless thing ... doth preservation seeke" (NT I447-48), and by whose law we know of the afterlife (I474-76); the light of nature is paired with the "light devine" (652), and nature's speech, "like Gods oracle," cannot lie (I 496). For Davies, then, nature is a name for God's instrumentality among humankind, and an index of undimmed human capacities. For Chambers, by contrast, not only are our natural powers not divine, they are antithetical to the action of divine grace. Hence, whereas Davies wrote of the spark of synderesis multiplying like flames "nourisht still, with new supplies of wood" (I I96), Chambers reaches for a very different metaphor:

Gloewormes, ould fishes bones, right rotten woode, such are the Sparkes that Heathen holde for deere: and builte unto themselves, all faulse for good, that Natures light, was light by Nature cleare. (fol. I6)

The human spark possesses not the incandescence of divine fire, but only the faint light of luminescence - of glow-worms, fishbones, and decaying wood, a traditional triad deriving from several ancient sources, although the original example was the nacreous shimmer of fish-scales. ${ }^{33}$ Again and again, capitalized Nature is depicted as lightless and blind. Chambers begins his section on the soul with a sarcastic invocation: "Nature where is thy Lyght, where is thy daye, / come give myne Understandinge some Assurance" (fol. 8). Its darkness is contrasted with the light of grace: "Grace cleares the cloude, which Nature drewe by Sin" (fol. 8); "Call we then for this Grace, the illightenninge Glasse, / despise the flashes of our Natures lighte" (fol. I6). Chambers is drawing on the traditional distinction, ultimately from I Cor. 2:I 4-I6, between the natural (psukhikos) and the spiritual (pneumatikos) man, the first trying to grasp the world by his own feeble lights, the second endowed by grace with higher understanding. As he expresses the point in prose, "the Naturall Man, be he

33. Aristotle, De anima, 4I9a5, mentions fungi and the scales and eyes of fish; in his commentary, Alexander of Aphrodisias, De anima libri mantissa, ed. Robert Sharples (Berlin, 2008), 69 (I28.5-7), mentions fishbones and heads and glowworms. Chambers' examples are given together in Conrad Gesner, De raris et admirandis herbis (Zurich, I 555), 6. Cf., e.g., Margaret Cavendish, Philosophical and Physical Opinions (I655), 78 (ch. I I4), listing "glow-worm light, rotten wood light, the light of fishes bones." On the topic more generally, see Philip Ball, Curiosity: How Science Became Interested in Everything (Chicago, 2012), 324-38. 
Artist or without Arte, Neyther knoweth nor can knowe, The high Estate of her [i.e., the soul's] devine Beinge" (fol. I9v). Nature is thus a shibboleth between the two poets: for one, it retains the imprint of divinity, for the other it is what divinity is defined against.

The poems also differ in their style, for despite Chambers' effort to imitate Davies, he is a far lesser technician, relying heavily, like a preacher, on short rhythmic devices such as tricolon ("Thy Hestes, the Lawes, thy Promyses," fol. 7), polyptoton ("the wisedome of the wise," fol. I Iv) and simple repetition ("holy holy Booke," fol. I3v). More crucial is the issue of articulacy, where we began this essay. If Nosce Teipsum suffered from incoherences under its eloquent surface, the Reformation is more overtly inarticulate, as we have already begun to see in its handling of traducianism. This aspect of the poem takes a number of forms. At its most brutal, it involves a blank repudiation of logical argument, coupled with a rejection of the fluency and sophistication of the original. Consider one extremely clumsy quatrain:

Why was the Soule, unto the Bodye knitt, for this, for that, or for another thinge:

To reason soe I leave it as unfytt, to prayse the Lord, thus doth Kinge David singe. (fol. I3v)

This stanza picks up on a recurrent rhyme on the phrase "to the body knit" (or close variants thereof), which appears seven times in Nosce Teipsum in reference to the soul or spirit. But Chambers' lines, unlike Davies', are full of waste: the second says nothing at all, and the fourth changes the subject entirely. Before he has even finished the unit of argument represented by the rhyme, Chambers has denied its premise. The contempt is palpable, and the rhetorical effect, if we allow ourselves to hear it, is more striking than any patient exposition would have been, because it dramatizes its core contention, dissolving Davies' metaphysics into a grey tedium that can be immediately contrasted to the simple, direct piety of Scripture. The aesthetic can also manifest in an awkward clink and jingle underscoring key assertions throughout the Reformation - "The zones, the Tropicke and the Poles, right well, / we thinke we knowe, but is our Thinke we knowe" (fol 6v); "The Seate of Soule, where God the Soule did sett" (fol. 9v); "Man Christ doth not, all whole Mankinde refine" (fol. I4v).

Elsewhere, the Reformation evinces a different sort of ineloquence: when Chambers tries to articulate the theological doctrines of the Bible, 
language fails him. One of his pet peeves is Davies' assumption that human beings are made in the image of God: "thy whole image thou in man hast writ" (NT I 266), "Mans soule which did Gods Image beare" (I2 I), and so on. This was of course Gen. I:27: "God created the man in his image: in the image of God created he him." But Chambers disagrees:

Lyke in Gods Image, was this Man ymade, I doe not saye, Gods Image was the Man: he rather was the Sample, or the Shade, of that same Image when he first began. (fol. 9v)

We are not an image of God, we are a "sample" (specimen) or "shade" (dim outline, phantom, reflection-equivalent to Greek skia or Latin umbra) of his image, at two removes, or rather at three, for we have since fallen and become even less similar to the divine. Chambers explains his reasoning in the prose gloss at the end: "Jesus Christ is the only Image \& likenesse of God his Father, And ... Adam was made like unto that Image or likenesse" (fol. I9). The first claim derives from Col. I:I5, where Christ is designated the eikon or image of the invisible God, although not the "only" one. The second claim seems to reflect a line from the seventeenth of the 39 Articles, that human beings "be made like the image"-not in the image- "of His only-begotten Son Jesus Christ"; but that statement was never intended to contradict the standard reading of Gen. I:27. The poem itself struggles to express the point:

There am I taughte, the Sonne of God to be, all fatherlike, whose Charector he is: lyke to that likenesse, there the Man I see, but not the Image, that were all amysse. (fol. $6 \mathrm{v}$ )

The syntax malfunctions, more Latin than English. "To be" here renders the infinitive esse required in indirect discourse, and is not the object of "taught," as natural English would suggest; "whose" must awkwardly denote the Father, following Heb. I: $3,{ }^{34}$ since Christ is "like" the Father

34. Here Christ is described as kharaktēr tēs hupostaseōs autou, the "character of his [God's] person." It is worth noting, however, that no early English translation, nor the Vulgate, uses the word "character" here; Chambers' language is learned. Character and image often went together in theological formulations of the sixteenth century; for instance, the Swiss reformer Ulrich Zwingli, 
(being his image and his "character," in the sense of a visible manifestation) as well as being "fatherlike," that is, paternal, towards us. Perhaps all this clumsiness could be spun as accurately reflecting the mystery of the Trinity, one in which Christ is at once the likeness, the impression, the image, and the physical (and soteriological) representative of the $\mathrm{Fa}-$ ther, not to mention the "radiance of his glory" (apaugasma tês doxēes, also Heb. I:3) and sundry other competing metaphors. But what is interesting about Chambers is that he attempts to exploit this cloud of meanings for leverage in his dispute with Davies, playing one part of the Christian tradition against another. The result barely makes sense: if we resemble that which resembles God, do we not also resemble God? Chambers is trying to carve a paradox out of subtle distinctions, in the way that Donne might, but instead he is left with a position lacking any basis in contemporary theology — or rather, a muddle.

Another example is still more curious. We have seen that Davies contradicted himself by dismissing the "all in all" doctrine of the soul before adopting it later. Chambers is categorically against it, although his preferred picture is unclear: "Not all in all, and all in every parte, / but all through all, this livinge Soule doth dwell" (fol. I4). Bowers comments, reasonably: "Chambers insists on the autonomy of the rational soul, although his language seems to be proposing a distinction without a marked difference." ${ }^{35}$ Perhaps it was the suggestion of containment to which Chambers objected, although, as we saw, the purpose of the original formula had been to both suggest and confute containment, and indeed the very spatiality of the soul at all. His own expression instead conveys movement. But where did he have it from? A similar formula appears in the work of the fourth-century Church Father, Gregory of Nyssa. Borrowing Plotinus' old comparison of soul and body to the diffusion of sunlight in air, Gregory stressed that the soul lacked spatiality since it was incorporeal: holè di' holou chōrei ... sōmatos, "the whole [soul] flows [or "advances," or "spreads"] through the whole body." ${ }^{36}$ This expression, in the Latin of Laurentius Sifanus' I 562 translation of Gregory, found its way into many textbooks, where Chambers may have encountered it. For instance, the

\footnotetext{
In Epistolam ad Romanos annotationes, at Rom. I3:I4, in his Sämtliche Werke (Leipzig, I905), 21.86, conveyed the point as follows: "Christus est imago et character dei patris, exemplar vivum et expressum substantiae dei."

35. Bowers, "An Elizabethan," I4.

36. Gregory of Nyssa, De anima, II. I I, in Patrologia graeca, ed. J.P. Migne, I6I vols. (Paris, I857-I 866), XLVI, col. 93.
} 
Italian Protestant divine Girolamo Zanchi, in his popular De operibus Dei (I 59I), explains, quoting Sifanus: "The soul exists in the body in such a way that it is all in all, and all in every part. This proposition is very frequent in Augustine and in some other Fathers, and indeed also in the Platonic writers. And they adduce this reason for why the soul is truly said to be, and indeed is, all in all the body, and all in each individual part: that is, because it is indivisible, since it is a spiritual substance, incorporeal and immaterial. Thus Gregory of Nyssa says that the whole soul, since it is incorporeal, and not circumscribed in place, passes through the whole body [tota per totum meat corpus]." 37 Note, however, that Gregory's formula is not contrasted to the more usual one, but offered as a variation on it. Indeed, Gregory himself wrote elsewhere of the soul as existing equally en pasi kai dia pantōn, "in all and through all" parts of the body; in both passages his primary goal, just like that of the Western theologians, is to confute the naïve idea that the soul is spatially located in one part of the body. ${ }^{38} \mathrm{It}$ would be a mistake, then, to see Chambers as selecting from a rival tradition of thought on the soul, and this excursus illustrates the pitfalls of reductively seeking sources for early modern poetry. Where we might expect Chambers to be learnedly exploiting a subtle but important distinction - a distinction whose importance we hope will reflect on us, its discoverer-we instead find him inventing one absent from earlier theological discourse, presumably for aesthetic rather than doctrinal reasons. Perhaps he liked the Nyssene formula simply because it differed, however superficially, from that of the pagan Aristotle. But as so often, the imperative of debate has carried Chambers beyond the limits of reason, and indeed of conceptual articulacy.

The critical consensus on Nosce Teipsum leaves us with very little reason to read it-perhaps only as a convenient index to one configuration of late

37. Girolamo Zanchi, De operibus Dei intra spacium sex dierum creatis opus (Neustadt, I 59I), 563a (2.6.5, "De unione animae cum corpore"): “Thesis III: Anima ita est in corpore: ut sit tota in toto, et tota in qualibet parte. Propositio haec frequentissima est apud Augustinum et alios Patres nonnullos: et vero etia apud Platonicos scriptores. Ac rationem adferunt, cur anima vere dicatur esse et sit tota in toto corpore: et tota in singulis eius partibus: nempe quia indivisibilis est: cum sit substantia spiritualis: incorporea, immaterialis. Ideo Nyssenus: anima (inquit) cum sit incorporea, et loco non circumscripta: tota per totum meat corpus."

38. Gregory of Nyssa, De hominis opificio, cap. I 5, in Patrologia graeca, XLIV, col. I77. 
sixteenth-century English theology and metaphysics. The poetry itself is incidental; we find it at best pleasant, a work of competent joinery, at worst dull, lacking drama. It aims to be what Stanley Fish called a "selfsatisfying" work, one that communicates a message about the world in plain, judicious language; and yet we might in fact be dissatisfied by its raising of radical doubt as to self-knowledge and then carrying on regardless.

Fish's categories of the self-satisfying and the self-consuming purport to denote two possibilities of the experience of reading. The problem is that Fish describes only his own experience and then assumes it to be that of an ideal reader; but an ideal reader is only another way of talking about the work itself. His two categories, though useful and interesting, turn out to have been formal ones all along. It is impossible to avoid relying on one's own experience, and I have done so in this essay too. But to evaluate the experience of a work it is a blessing to have others, and above all contemporary ones. Such evidence is precisely what Robert Chambers offers us, for the Christian Reformation is, if nothing else, the record of a reading of Nosce Teipsum. And it underlines an important fact ignored by Fish, namely, that early modern reading was more often combative than disinterested, with unpredictable results: a gesture meant to satisfy the reader's self could provoke instead hostility and disobedience.

Davies wanted assent, commendation, patronage; Chambers gave him quibbling. That quibbling is faulty, as we have seen: the Reformation is unsophisticated, repetitive and verbally clumsy, fabricating dissent from the flux of images and metaphors in the Christian tradition, and failing to convey in iambic pentameter what its prose paraphrase tells us it meant to say. But the result is, if artless, surprisingly close to what Fish values in the selfconsuming text. By affecting a distinction between soul begetting soul and human begetting human, or between man as God's image and man as like God's image, or between the soul existing all in all and all through all, Chambers invites his readers to think for themselves about what those distinctions might realistically entail, and, by extension, about how close our language, above all that of poetry, with its inevitable recourse to figures, might come at all to truth on such matters. In other words, the ineloquence of Chambers' poem makes it both the ideal counter to the authoritative smoothness of Nosce Teipsum and a reproof to its assumptions: how better to drive home our fallen incapacity for self-knowledge than to dramatize our inability to speak coherently of the human mysteries? The Reformation is worth our time not because it gives us fine quatrains or convincing arguments, but because it conveys self-knowledge as a struggle, even a 
futile one-which indeed it may be. The real failure of the poem, with all its pathos, seems from this perspective a greater success than the slick legerdemain of Nosce Teipsum, and, more pertinently, than the Reformation itself would have been if competently written. Ironically, Davies himself had suggested why this might be. Early on he argues that hardship is a powerful prompt to self-examination:

If ought can teach us ought, Afflictions lookes, (Making us looke into our selves so neare)

Teach us to know our selves, beyond all bookes, Or all the learned Schooles that ever were.

All Davies holds out to us, however, is yet another addition to those "bookes"; 39 it is Chambers, by contrast, in his polemical awkwardness, who afflicts our comfort. That is why we must resist any critical impulse to defend the poem by revealing hidden depths in it, or by seeing in it a valuable witness to this or that species of early modern theology. Such an impulse betrays our misleading perception of ourselves as intercessors between lay readers and the arcana of history; to seek that role is to risk making ourselves the target of Chambers' mockery, and to forget that the light we shed on past artefacts is less a solar radiance and more the glimmer of fireflies, or the glow of timber rotting in a dense forest. We need humility, but also a clear idea of what criticism can and cannot give us. Even if the Reformation warns us to abandon our presumption to self-knowledge, that knowledge is what we have most to cultivate as critics in an age with so few shared intellectual aims. Indeed, our cultivation of it must not be distinct from the business of criticism itself.

UNIVERSITY COLLEGE LONDON

39. Cf. Murphy, "Fulke Greville's Figures," 250-5I. 
Appendix

The following extract offers in its entirety the shorter first section of the poem, "Of humane knowledge," which corresponds to the equivalent section in "Nosce Teipsum".

\title{
A christian Reformation of Nosce teipsum
}

Of humane knowledge

\begin{abstract}
Allmyghtye God, who only art, I am, of Beinges all, Beginnings, and before: Even in thy Mercye, who becamst the Lambe, ere fallinge was, the ffallen to restore.

Eternall euerliuynge Spirite of Grace, in Oneheade One, yet Thride amongst the Three: Who didest preserve, uppon the waters face, the Masse create, One, All, assistinge be.

Thy clensynge droppes, from bunche of Isope cast, make them $\mathrm{O}$ Lorde, my fleshye thoughts refyne: Whole Man is Man, oh lett me wholly Taste, thy Grace for grace, thy Grace my guide assigne.

O God, god of my strength, I laboure all, to speake the Truthe, what of my selfe I knowe: Nor Arte, nor witt, nor ought on Earthe I call to helpe: they are but cyphers in the Rowe.
\end{abstract}

They only Rayse the Som[m]e beyonde accompte, and tell the Greatenesse of thy Bountye muche when Arte, nor witt, nor ought can here amounte, to goe for ought, is any Bountye suche?

Philosophers, with Rules of Arte, and skill they haue sett forth an Orator to tell: He knowes himself; But they haue taught him ill, directe $\mathrm{O}$ Lorde, he be reformed well. 
Whilst on the Stage arayed wth all the Store that Roome or Athens yeldes for such disputes he of the Soule \& Bodye tells, and more, of Gods Decrees, ould Adam he confutes.

And ffirst he doth pronounce his Lust a Synn, before there was a Lawe, to binde Desier: concludinge, all o[ur] Manhoode drownde therin whilst Adams will, did will, and wrought no hyer.

As if Mans will, had not bin lefte him free, or Eatynge thou shalte Eate, were sayd in uayne of all the Trees w[hi]ch in the Gardeyne bee, in Love I warne of one, but not restrayne.

That lust callde Eateinge on, who can denye, yet Lust was not, the foremoste, in the Ill. I knowe that Deathe did enter all the Eye, but Eateinge, whollye did corrupte the will.

Euen soe, that now, Lust both conceaves the Sin, and is in Sinn compleate, it selfe alone:

Noe tyme there is to saye it doth beginn, Beginninge now, makes Acte \& Ende but one.

Though att the first I reede of no Decree, nor any Lawe pronouncinge Lust a Sinn: And Synn without a Lawe could neuer bee, St Paule doth give a sacred Rule therin.

Moses hath shewed what Sathan did suggest, what blindnes of Mans harte I doe not see: But Death to Taste the fruite I fynde exprest, w[hic]h Heua knewe, before she toucht the Tree.

And did att first assaulte the Serpent tryse assuringe they might Eate yf they woulde dye That ere he could preuayle in his deuise, he diude [marg: duct] beyonde their reache into a Lye.

And all beleagerd Man, w[hic]h God doth knowe, the Multytudes and Troopes of w[hic]h Araye, 
Euen with theyr Soude did Adam overthrowe, through which his will nor witt could worke a waye.

Addinge withall, as soone as they did Eate, they shoulde as Gods knowe clearlye good \& ill which guilefull Glorye drewe them to the meate, and did vnfaythfull, hopefull Adam kyll.

Whose Hope was yett, to Taste the kernell vayne he brake his Teeth, in crackinge of the Shell. The light of Good \& Ill increast the payne, when with the Good he had no power to mell.

Knowledge alone, was made the serpentes Hooke, vnbeinge Ill, was soe contrivde therin:

who sought for knowledge in the Baite was tooke, and mighte not misse, the daunger of the Synn.

Adam desiered never Ill to knowe, knowledge he sought, he did noe ill pretende: But ill with knowledge then lay myngled soe, that Love to knowledge, drewe him to Offende.

Thus was the creature caught, thus overthrowen, whilst under Hope, he sett himselfe to prye: Into Gods knowledge, all to him unknown, how Good and Ill, did in that Seacret lye.

This well I fynde, in thys we all agree, each Mynute spente in lewde and Idle lyne: is but agayne, to tast forbidden Tree, it favors not vnto the Soule devine.

Rest we on this, and soe peruse the Ryme, all proyned cleare, of letters that abounde: That christallise, the Argumente may shyne, single, alone, noe gloseinge Arte be founde.

Soe shall we see, ere o[ur] Lampe be spente, and ere the Sprite be dulld, or bodye wann. Tourninge one volume only, that we hente, more then att fyrst, was in the Power of Man. 
And fullye knowe, that through the Eye \& Eare, this dyenge sparkell, in this clowdye place:

Can recollecte more gloryouse knowledge here then was infusde in the first Man, by grace.

There may we see the Soule, as first shee was, as now she is, and as shee shalbe then:

When fyery flames, hath puryfyed the Masse, and Doome disceaverd, all the Sonns of Menn.

The zones, the Tropicke and the Poles, right well, we thinke we knowe, but is o[ur] Thinke we knowe:

Or tryed by the Lyne that Truthe doth tell, our lessons all, then should we learne anewe.

The lawe writt in o[ur] harts, workes not soe highe, to teach o[ur] selues, o[ur] selues in all to knowe: That Skill to Soules, Grace only suer doth tye, and to o[ur]selues o[ur]selues doth playnlye shewe.

Scearche then the Booke, vaine fabells viewe refrayne, reade there the Deede, that Heauen doth entayle: There see thy Soule to rente, and healde agayne, by Him that did ore Deathe \& Hell prevayle.

That Lady cowe, how dare I mention here, or quitt the worke, with such a fabled Lye: Or saye the Soule, did once, Gods Image beare, in that same Booke, this never learned I.

There am I taughte, the Sonne of God to be, all ffatherlike, whose Charector he is: lyke to that likenesse, there the Man I see, but not the Image, that were all amysse.

Nor from herselfe, can Soule be said to tourne, but from her Bodye, from hir dirtye venn: She twynes and windes herselfe, and much doth moorne, from Sluttishe feeres, as doe the neater Menn.

This well I wote, Affliction humbleth muche, and warnes of that, we heeded not before: 
Yet say I not, her able Strength is suche, then holy Bookes, her Teachinge to be more.

I list not amplifye Affliction soe, when Singer sweete unto the lord did saye: O lorde tis good, that thou hast brought me lowe his Sauinge healthe, he founde another waye.

Thy Hestes, thy Lawes, thy Promyses, be sweete, they make me wyser, then my teachers bee: By Them $\mathrm{O}$ lorde, make me dyrecte my feete, and all thy comfortes thus, myne Eye shall see.

Affliction then, may not comparinge goe, to matche the Mr. teachinge all on hye: Her offyce wayteth att the Doore belowe, to call them, in the Labor to applye.

But Cynthius now, me thinke, myne Eare doth nipp, and if I knowe my selfe, he biddes me tell: Or els to laye my finger on my lipp, singe not att all sayth he, or els singe well.

I knowe my Bodye formed of the Dust I knowe my Sprite inspird from God aboue: I knowe my will did rule them as it luste, I knowe my Fact did all my good remoue.

I knowe that Grace, hath couered all my Sin, I knowe the Sonne hath rectifyed my will: I knowe my Fayth the victorye doth winn, I knowe withall, my feeble stacyon still.

I knowe my workes my Brother must assure, I knowe my Loue, or els I needes must dye: I knowe that Christ doth all to me procure, This of my selfe I knowe not, this knowe I

All comforte in knowledge. 